\title{
Introduction: Europe from Below
}

From its inception, the principal idea of the European project was to unite people and to form a 'community of Europeans' based on the values of peace and reconciliation, which would make it possible to move beyond a national perspective and instead foster better relations among European nations by promoting cooperation and tolerance (see Monnet 1955; Schuman 1963). The preamble to the Treaty of Paris (1951), formally establishing the European Coal and Steel Community, expressed precisely this aspiration:

to substitute for age-old rivalries the merging of their essential interests; to create by establishing an economic community, the basis for a broader and deeper community among peoples divided by the bloody conflicts; and to lay the foundations for institutions which will give direction to a destiny henceforward shared.

The founders of the European Coal and Steel Community were clear about their intentions for the Treaty, namely that it was the first step towards European integration resulting in close collaboration between its member states and culminating in the idea of a united Europe.

Culture can be considered as one of the underlying ideas that have motivated the creation and building of the European Community (EC) and, later, the European Union (EU) (e.g. Rosamond 2000; Sassatelli 2006; Näss 2009). The EC started its culture-focused activities in the 1970s, and has used cultural aspects as central elements in promoting integration since the mid-1980s (Shore 1993; Shore 2000, 25). With the Maastricht Treaty in 1992, culture was made an official policy field of the EU. Since then, cultural policy has been perceived as an increasingly central area for the Union (Näss 2010; O'Callaghan 2011). The establishment of European cultural, heritage, and remembrance policies over the last few decades can be interpreted as extending and deepening the European project by emphasizing the cultural-historical underpinning of the Union that has long been viewed mainly from economic and political perspectives (Prutsch 2013, 36). Scholars have discussed this process with the concept of 'cultural Europeanization', which refers to policies and practices dealing with being or becoming European through culture. It has been

(C) TUULI LÄHDESMÄKI ET AL., 2021 | DOI: 10.1163/9789004449800_001 
interpreted as the third wave of the integration process, in which European integration broadens from economic and political spheres to encompass culture (Delanty 2005; Sassatelli 2006, 2008, 2009; Jarausch 2010; Karlsson 2010; Patel 2013; Lähdesmäki 2017). In these views, cultural Europeanization is mainly understood as a top-down process initiated by the EU.

Since the 1990s, the EU has increasingly developed a particular European discourse based on a transnational 'European' interpretation of culture and heritage across national differences. It began to narrate this amalgam of a multitude of types of knowledge, attitudes, and values to a wider public as the story of 'Europe'- of what Europe is, who Europeans are, and the elements which make up their 'Europeanness' (see Karlsson 2010; Lähdesmäki 2017a; Lähdesmäki et al. 2020). Since then, the EU has been increasingly interested in its own and Europe's past - pasts that are commonly paralleled in EU policy rhetoric. While 'flirting' with the imagination of a shared European past and heritage, this EU discourse is simultaneously extremely future-orientated. The narrations of Europe's past and common heritage function as building blocks which the EU uses to create a particular image of itself and 'its' citizens, and to educate future 'Europeans' (Lähdesmäki 2014a).

The EU's need for a narrative that would increase unity in Europe and promote acceptance of European integration has become urgent during the past decade due to the serious economic, political, and humanitarian challenges that the continent and the Union have faced. These challenges range from struggles of the Eurozone and European financial markets to the dispute among EU member states regarding further integration and enlargement of the Union, and include diverse political crises stemming from the EU's legitimation and democratic deficits, which connect to the rise of Eurosceptic political parties demanding to exit the common currency zone and/or the European single market and political institutions. Diverse populist, nationalist and radical right-wing parties and groups, and their increasing public acceptance across Europe, have caused additional challenges. The sudden arrival of a great number of people fleeing violent conflicts and harsh living conditions to Europe in 2015 has exacerbated the political crisis, as contradictory views on how to deal with this mobility exist within the EU and its member states. At the same time, the EU has struggled with its own identity crisis (Jenkins 2008), which stems from the difficulty of narrating a common story of Europe (Lähdesmäki et al. 2020). The EU cultural policy discourses, with their emphasis on constructing a common cultural area and a feeling of belonging to Europe and the EU, can be perceived as the Union's response to these diverse challenges. The EU's interest in tackling these challenges is reflected in its policy discourses in various sectors and concretized in EU cultural initiatives that seek to implement these policies and move their discourses into practice. 
In this book, we scrutinize EU cultural policy as politics of belonging (Yuval-Davis 2006, 2011), particularly from the perspective of participants in the EU's cultural initiatives. In this context, we understand politics of belonging as attempts to create a cultural narrative for Europe in order to promote a sense of belonging to Europe and the Union in terms of a cultural community among EU citizens and to strengthen their identification with the EU through the means of participation in culture. We view the EU's politics of belonging as an act of power based on the utilization of diverse discursive, narrative, and cultural resources to construct Europe and the 'European' and as a means to justify specific policies to do so (Lähdesmäki 2020; Lähdesmäki et al. 2020).

The EU's cultural initiatives can be seen as instruments in the EU's politics of belonging. Through them, the EU constructs and creates the idea of Europe, a category of Europeans, and a set of features that define them. This goal is often explicitly stated in the EU's cultural policy documents. For instance, by defining the objective to create a "common cultural area" and strengthen a "feeling of belonging" to it among citizens (e.g. EP\&C 2006, 2, 4; EP\&C 2013, 3), such policy documents provide evidence of how, in the EU's politics of belonging, cultural initiatives are used to both define and convey notions about Europe and the 'European' to a wider public.

Since the turn of the millennium, the EU has governed its cultural sector through large funding programmes that typically run in seven-year intervals. The first of these programmes, Culture 2000, ran from 2000 to 2007, and was followed by the second Culture programme from 2007 to 2013. The current programme is called Creative Europe and is running from 2014 to 2020 . From these programmes, the EU finances various temporary projects organized by micro and meso level actors. One of our case studies in this book, the European Citizen Campus (ECC), is an example of these small-scale temporary projects. In addition, the EU allocates some funds from its cultural programmes to cultural initiatives that the European Commission itself regularly runs. Two of these initiatives, the European Capital of Culture (ECOC) and the European Heritage Label (EHL), are selected as cases for this book.

In terms of budget, culture represents a tiny EU policy sector. The Union does not have similar legal authority in this area compared to its core policy sectors, such as economy and trade. Even though the culture article in the Maastricht Treaty, adopted in 1992, and the following EU treaties allow the EU to develop overarching cultural policies, its member states are responsible for their own cultural policies according to the subsidiarity principle. Hence, the EU cannot exert direct influence on cultural policy at the national level. The whole idea of an EU cultural policy has therefore been considered controversial. Scholars have emphasized the complexity of decision- and policy-making in EU cultural policy as well as its symbolic nature due to its "soft law" instruments, such 
as non-enforceable recommendations and incentives (Dewey 2010). Several researchers of EU cultural policy have scrutinized its discourses and rhetoric, and identified vagueness, limitations, or conceptual contradictions (e.g. Shore 2006; Gordon 2010; Cooke and Propris 2011; Lähdesmäki 2012). Others have critically discussed weak links between ambitious goals and idealistic rhetoric in EU policies and the reality of their implementation (e.g. Mattocks 2017).

Nevertheless, the EU's cultural agendas, initiatives, actions, programmes, and policy goals affect both the cultural sector and cultural actors in the member states (e.g. Dewey 2010, 116). EU cultural policy has an important role in producing images, representations, narratives, cultural meanings, sentiments, and emotional bonds regarding the EU and Europe - in other words, it has an important role in the EU's politics of belonging. Being simultaneously cognitive and affective, the EU's cultural policy discourses and initiatives seek to appeal to cultural and social attachments and identity by disseminating knowledge, as well as by touching people on the emotional level (Lähdesmäki $2014 \mathrm{~b}, 2017$, forthcoming). For example, the rhetoric of EU cultural policy is characterized by eloquent usage of broad and abstract but rarely explicitly explained concepts of culture, heritage, values, and their supposedly shared features (Lähdesmäki 2017b; Lähdesmäki et al. 2020). This symbolic nature has been conceived as the key to the power of EU cultural policy: its seeks to 'touch' people's emotions, raise interest in and curiosity towards Europe' past and present, enhance positive attitudes towards the EU, and make Europeans feel European - in brief, to 'win the hearts and minds' of Europeans (see Patel 2013; Lähdesmäki 2017b). Young people are the explicit target audience of some EU cultural initiatives, such as the EHL; the aim is to advance their belonging to Europe and the EU.

The power of EU cultural policy is embedded in the way it is used to govern cultural matters. EU cultural policy is based on the model of multilevel governance that characterizes EU policy-making in general (e.g. Hooghe and Marks 2001; Bache and Flinders 2004; Nousiainen and Mäkinen 2015; Lähdesmäki et al. 2020). This means that governance is not centralized but is based on interdependent and simultaneous acts of governing at different levels, including diverse formal and informal networks of actors in the processes of governance. Moreover, the EU has recently emphasized participatory governance in its cultural policies (Lähdesmäki et al. 2020). This model of governance seeks to include diverse non-governmental actors in policy-making processes, such as cultural stakeholders, scholars, experts, representatives of civil society organizations, and citizens.

Even though both multilevel and participatory governance of culture aim at involving citizens in policy-making, both governance models present 
challenges. While multilevel governance seeks to encourage various actors to participate in the processes of governance, it may simultaneously complicate governance by spreading it to different levels (Piattoni 2009, 164). Similarly, participatory governance seeks to encourage citizens to get involved in various participatory practices. This may be mere tokenism, however, as someone else at a 'higher' level defines the conditions of participation and continues to hold the decision-making power (Lähdesmäki et al. 2020).

Nevertheless, the multilevel and participatory governance in EU cultural initiatives mingles top-down and bottom-up dynamics between the EU and local cultural actors, and thereby increases the variety of 'voices' included in the implementation of these initiatives (see Sassatelli 2006; Lähdesmäki 2014b; Lähdesmäki et al. 2020). The EU cultural initiatives seek to influence EU citizens' notions of Europe, co-construct a shared European culture and heritage, and affect a feeling of belonging through top-down policies with specific procedures and listed criteria for local actors implementing the initiatives. However, these local implementors have the power to interpret the identity-political aims of these initiatives from their own perspectives.

We argue in this book that cultural Europeanization - policies and practices dealing with being or becoming European - is an interrelated process that emerges in networked diversity and connectivity between various actors, in which they actively participate (see Chapters 2 and 8). For analytical reasons, we identify these actors and their discourses as representing macro, meso, and micro levels to distinguish the different institutional contexts and horizons of expectation from which the notions, discourses, and narratives of Europe are constructed. We perceive the EU as a macro-level actor that seeks to explicate and transmit specific notions of Europe to the wider European public through the conceptualizations and expressions used in its cultural policy discourses. Even though the EU itself is a composition of several institutions, which rarely take unanimous decisions, its policy discourses form a single 'voice' that represents the view of the EU as a political actor. The meso-level actors in EU cultural policy include national and local cultural managers, directors, and other facilitators who implement these policies in practice by organizing cultural events under EU cultural initiatives. These actors need to follow the macrolevel 'voice' but at the same time they are both able and expected to fill open, empty, or undefined contents of the EU discourse with their own 'voices'. We mean by micro-level actors people who participate in the cultural activities funded and governed through the cultural initiatives of the EU. These actors do not have any official role in meso- or macro-level practices. The identification of these three levels aims at clarifying our analysis and arguments. It does not seek to suggest that these levels are stable or actors could not move 
between them. Our analysis focuses on actors who represent the micro level in our categorization, and who in our case studies are 'ordinary' citizens who participate in and visit three selected cultural initiatives.

What kind of 'voices' exist and can be heard at the micro level? In this book, we argue that the constructions of the ideas of Europe and the 'European' in EU cultural initiatives need to be scrutinized not only from above but also from below. We use flexible and multifaceted methodology to analyze how the participants of the EU cultural initiatives construct perceptions of Europe and the 'European' and their own relations to them. Our aim is not to study the reception of the notions of Europe constructed in EU cultural policy. However, our case studies enable scrutinizing how people's personal conceptions of 'a community of Europeans' relate to the 'voices' and discourses at the macro and meso levels. Our research thus also brings new understanding on how the EU's politics of belonging is perceived and functions at the micro level. We continue this introduction by backing up our argument through a review of the existing literature on EU cultural policy and pointing out gaps in it. After this, we introduce our three cases embedded in the EU's cultural policy - the ECOC, ECC, and EHL. The examination of these case studies is based on broad ethnographic field research, which generated manifold data. After that, we outline how the notion of Europe has been addressed in the previous research. We end this chapter with a brief introduction to our theoretical approach, discussed more deeply in Chapter 2, and an overview of the book's structure and contents.

\section{EU Cultural Initiatives - Often Approached from Above}

In the scholarly literature discussing the development, conceptual choices, and thematic foci of EU cultural policy (e.g. Shore 1993; 200o; Sassatelli 2006; 2009; O'Callaghan 2011; Näss 2010; Patel 2013; Lähdesmäki 2014a, 2014b, 2016; Lähdesmäki et al. 2020), the focus and theoretical approaches taken vary greatly. Researchers have explored EU cultural programmes by perceiving them as the core documents communicating the EU's cultural political views, priorities, and values (e.g. Psychogiopoulou 2008; Mäkinen 2012, 2014; Kandyla 2015; Suárez and Luz 2018). Moreover, these programmes have served as data for analyses of specific topics ranging from audience building (Potschka, Fuchs, and Królikowski 2013) to cinema (Liz 2016), and from the construction of citizenship (Mäkinen 2012) to EU enlargement (Vos 2017). However, the researchers have less approached EU cultural programmes from the perspective of participants' experiences of being part of the European project and how these experiences have an impact on their notions of Europe. 
Scholars have explored EU cultural programmes and particularly some of its long-term cultural and civic initiatives, such as the European Capital of Culture. The ECOC initiative and the designated cities have been actively investigated since the 199os. This research has particularly focused on EU cultural policies and policy discourses, cultural management in the implementation of the initiative, and views and experiences of cultural managers and decision-makers in the ECOCs (e.g. Richards 2000; Sassatelli 2002, 2006, 2009, García 2004a, 2005; Lassur, Tafel-Viia, Summatavet and Terk 2010; Bergsgard and Vassenden 2011; Patel 2013; Žilič-Fišer and Erjavec 2017). Moreover, cultural regeneration, urban transformation, regional development, and cultural and creative industries have had a strong role in the research on ECOCs (e.g. Heikkinen 2000; Richards 200o; García 2004a, 2004b; Rommetvedt 2008; Campbell 2011; Hudec and Džupka 2016). These studies reflect the development of urban policies during the first decades of the initiative: the ECOC was introduced at a time when culture-led approaches to urban development and ideas of cultural regeneration of economically regressed cities were about to emerge (Sassatelli 2009, 95).

Much of the previous ECOC research has focused on the impacts of the initiative at the local level. These studies have explored diverse issues ranging from the tangible cultural outcomes to the residents' and visitors' impressions of the city in question (e.g. Richards and Wilson 2004; Berg and Rommetvedt 2009), and from the networks of cultural actors (e.g. Bergsgard and Vassenden 2011; Campbell 2011) to the economic impact, measured for instance through hotel stays and tourist visits (e.g. Herrero et al. 2006; Richards and Rotariu 2011; Falk and Hagsten 2017). The impacts of the initiative have also been a key focus of the ex post evaluations commissioned both by local authorities and the EU. In addition, scholars have been interested in the media discourses and representations of the designated cities (e.g. Aiello and Trulow 2006; García 2005, 2010). The impacts of the ECOC initiative have typically been analyzed by taking one ECOC as a case study. However, some broader investigations have applied a comparative approach (e.g. Myerscough 1994; Palmer 2004a, 2004b; Palmer and Richards 2007, 2009; Sassatelli 2009; Palmer, Richards, and Dodd 2011, 2012). Previous explorations of the ECOC initiative have considered the construction of European identity (e.g. Hansen 2002; Reme 2002; Sassatelli 2009). Nevertheless, we still need a deeper analysis of the visitors to ECOC events and how they construct the notion of Europe and their 'Europeanness' while participating in the EU initiative that explicitly seeks to increase their belonging to Europe (see however Lähdesmäki 2014c, 2014d, 2014e).

Compared to the ECOC, the EHL is a much more recent EU initiative. This is reflected by the quantity of research exploring it. The EHL has been 
analyzed in some studies as part of EU cultural and heritage politics and policies (e.g. Calligaro 2010, 2013; Kaiser 2014; Lähdesmäki 2014a, 2014b, 2016, 2017b; Niklasson 2017; Jakubowski, Hausler, and Fiorentini 2019; Lähdesmäki and Mäkinen 2019; Lähdesmäki, Kaasik-Krogerus, and Mäkinen 2019; Zito, Eckersley, and Turner 2019). The authors of this book have previously published an in-depth analysis of the implementation of the EHL initiative, approaching it from various perspectives, such as governance, geopolitics, participation, and gender (Lähdesmäki et al. 2020). Our research team has also analyzed exhibition narratives at several heritage sites awarded the EHL (Kaasik-Krogerus 2019; Čeginskas and Kaasik-Krogerus 2020; Turunen 2020). In the research on the EHL initiative, there is little in-depth exploration of visitors' experiences and their perceptions of Europe and the 'European' at heritage sites that are required to emphasize a 'European dimension' of cultural heritage.

Our review of the existing literature indicates that deeper qualitative analyses of the notions of Europe and the 'European' among participants in EU cultural initiatives are few. Even fewer are studies that compare such qualitative results between different initiatives. Our book seeks to fill this research gap at the intersection between studies of EU cultural policy, European identity and belonging, and visitors. Moreover, our book offers a comparative and longitudinal approach to the construction of Europe from below. Our case studies cover the period from 2010 to 2018. Our longitudinal approach enables us to analyze transformation and stability in the notions of Europe and the 'European'. It is motivated by the recent transformations in Europe: as discussed above, the EU has begun to search for a new inclusive European narrative in order to increase belonging to and unity in Europe as a response to the various challenges of the 2010s. Our data includes material from 12 countries belonging to Western, Southern, Eastern, Northern, and Central Europe. Our comparative approach goes beyond comparing the findings from our three cases and makes it possible to explore the participants' notions of Europe in relation to various demographic factors, such as their geographical location, gender, age, education, and cultural participation.

Three Cases: The European Capital of Culture, European Citizen Campus, and European Heritage Label

The three cases discussed in our book, the ECOC, the ECC, and the EHL, share certain similarities. All three have been funded from the EU's cultural programme; thus they follow the EU's cultural political agendas and have similar policy goals, such as promoting Europe's cultural diversity and shared heritage, 
promoting intercultural dialogue, and strengthening a feeling of belonging to Europe and the EU. Yet, they differ in terms of implementation, funding, length, and the number of people they reach. The initiatives also represent divergent foci in EU cultural policy - urbanity, citizenship education through creativity, and cultural heritage. These cases reflect the cultural and identity political interest common to many EU cultural initiatives and offer manifold data to explore the notions of Europe among their participants. As a case study, our research does not seek to generalize our findings to cover all EU cultural initiatives.

The ECOC initiative was launched in 1985 , when the ministers of cultural affairs in the member states of the European Community adopted a resolution to hold an annual event named the European City of Culture. The initiative was run as an intergovernmental scheme until 1999, when it was transformed into an official action of the European Parliament and Council and renamed the European Capital of Culture. The new official status of the initiative did not have a major impact on its EU funding but it enabled the Union to formulate a more detailed set of regulations, criteria, and guidelines for its implementation (Oerters and Mittag 2008, 75). The annual process of selecting the Ecocs is based on applications from candidate cities. They first compete for the designation at the national level. National panels in the member states suggest their final candidates to an international expert panel appointed at the European level. Based on the selection of this panel, the European Commission finally designates cities as ECOC. Since 1997, it has been possible for several cities to be designated simultaneously. By 2020, 62 cities have celebrated their designation as European City/Capital of Culture (see the list of Ecocs in Annex 2).

During the past decades, the implementation of the ECOC initiative at the local level has undergone various changes as the cities have aimed to utilize the designation to further current cultural and urban policies (Lähdesmäki 2014e). Over its history, the ECOC designation has developed from a short-term cultural festival into a year-long urban event that enables economic and social development of the city, regeneration of the city space, and participation of civil society actors in various political and cultural processes in the city (see Richards and Palmer 2010, 205-206; Sassatelli 2013, 64-66; Staiger 2013, 33). The ECOC initiative includes some funds allocated for the selected cities. Since 2007, the EU has supported each ECOC with a Melina Mercouri prize of 1.5 million euros. Yet, the EU funding still comprises only a small fraction of a city's total budget for the ECOC year.

One of the central purposes of the EU cultural programmes is to distribute financial support for multi-annual cooperation projects in the field of culture. In these programmes, the European Commission opens calls for proposals for 
general cooperation projects as well as thematic calls for operators in various fields of culture. The small-scale projects must include a project leader and at least two partner organizations from at least three countries, while the largescale projects must have at least five partners in addition to the project leader from at least six countries. The maximum duration of all the projects is four years. The projects funded through the EU's cultural programmes are a central way of putting the policy discourses of these programmes into practice. As an example of the projects funded through the EU's cultural programmes, our book explores the ECC.

The ECC was an EU-funded temporary project launched in 2013. It focused on citizenship education through artistic laboratories that took place in summer 2014 in six European countries. A total of 144 students from various universities in the Netherlands, Luxemburg, France, Germany, Italy, and Portugal worked in thematic laboratories led by 12 artists. The themes and the host cities of the laboratories were: identity in Antwerp, dialogue in Luxembourg, roots in Strasbourg, home in Freiburg, conflict in Padova, and freedom in Viana do Castelo. The art forms used in the laboratories included painting, clay work, sculpture made from waste material, illustration, photography, dance, and music. Through artistic work, the students elaborated on the themes of the laboratories. The project ended with a final conference and an art exhibition organized in Antwerp in June 2015.

The EU's most recent heritage action is the European Heritage Label. The EHL is not a funding instrument as it does not include any regular financing measures for the sites but rather focuses on networking and cooperation among them. The scheme was launched in 2006 as an intergovernmental initiative run by the EU's Ministries of Culture. By 2011, 68 sites had been awarded the Label. It was considered difficult to effectively implement the initiative on an intergovernmental basis due to the lack of coordination and opportunities for operational arrangements (Lähdesmäki 2014a). Yet, the scheme was considered important by the European Parliament and Council, and in 2008 the Council adopted conclusions transforming the initiative into an official EU action. Previously awarded sites were required to reapply for the 'official' Label. The idea of heritage is understood in the EHL action both in tangible and intangible terms, as the decision defines heritage as "monuments, natural, underwater, archaeological, industrial or urban sites, cultural landscapes, places of remembrance, cultural goods and objects and intangible heritage associated with a place, including contemporary heritage" (EP\&C 2011, 3).

The European Commission used the ECOC as a case in point for establishing the EHL. Therefore, the selection procedures in these two initiatives are 
similar. The EHL sites are first pre-selected at the national level. The final selection is then made by an international expert panel appointed at the EU level, and the Labels are awarded for the selected sites by the European Commission. In contrast to the ECOCs, the EHLS are selected biannually and the award is permanent. The sites may, however, lose their Label if they do not continue to fulfil the criteria of the action during the monitoring processes. The number of labelled sites in each labelling year has ranged from four to 16 . As of 2020, 48 sites from $19 \mathrm{EU}$ member states have been awarded the official Label. These sites vary from well-known tourist attractions, such as the Acropolis in Athens, Greece, to lesser-known and smaller sites, such as the Franja Partisan Hospital in Slovenia, and from high cultural sites, such as Franz Liszt Music Academy in Budapest, Hungary, to sites of the EU's political history, such as places related to the negotiation of the Maastricht Treaty in the Netherlands (see the list of EHL sites in Annex 3). The sites date from Neanderthal times to recent decades.

Our case studies of these three EU cultural initiatives have been conducted as part of different research projects over the past decade. The first of them focuses on the ECOC initiative, covering three cities: Pécs in Hungary, ECOC in 2010; Tallinn in Estonia, ECOC in 2011; and Turku in Finland, ECOC in 2011. The second study explores the ECC project, focusing on its implementation in Strasbourg, France and Freiburg, Germany. Moreover, this case study includes participant observation in the final conference of the project in Antwerp, Belgium. The third study examines the EHL in 11 heritage sites: Alcide De Gasperi's House Museum, Italy; Archaeological Park Carnuntum, Austria; Camp Westerbork, The Netherlands; European District of Strasbourg, France; Franz Liszt Academy of Music, Hungary; Great Guild Hall, Estonia; Hambach Castle, Germany; Historic Gdańsk Shipyard, Poland; Mundaneum, Belgium; Robert Schuman's House, France; and Sagres Promontory, Portugal.

The analysis of the three cases is based on ethnographic field research that included various modes of observing the implementation of the initiatives and people who participated in them, or, in the case of the EH L, visited the heritage sites and their exhibitions. The field research for the ECOC and the ECC cases was conducted by only one of the authors of this book, Lähdesmäki for the ECOC in 2010 and 2011 and Mäkinen for the ECC in 2014 and 2015, respectively. In contrast, EHL case study is based on team ethnography jointly conducted by the book's four authors in 2017 and 2018. The research team included a fifth scholar, Johanna Turunen, who did not co-author this book. We have discussed our epistemological approach to team ethnography and practices, including our experiences with it, in depth elsewhere (Lähdesmäki et al. 2020; Turunen et al. 2020). Although all four of us did not participate in the field research of 
all three case studies, for this book, we analyzed and discussed them collaboratively, based on extensive knowledge exchange, sharing our ideas, findings, and experiences, and writing the book together.

\section{Previous Discussions on the Idea of Europe}

The research on the idea of European identity as such has a long tradition in academia. During the past decades, scholars have extensively explored the construction of European identity in relation to social, political, and cultural transformations in Europe, the development of the EU, and European integration (e.g. Risse 2003, 2006; Bruter 2003, 2004, 2005; Herrmann and Brewer 2004; Mayer and Palmowski 2004; Beck and Grande 2007; Antonsich 2008; Pichler 2008, 2009; Checkel and Katzenstein 2009; Kaina, Karolewski, and Kuhn 2015; Triandafyllidou and Gropas 2015; Waechter 2019). In addition, identifications of Europeans have been regularly investigated through broad surveys, such as the European Value Survey and Eurobarometer surveys.

The European integration process and the development of the EU has generated extensive academic literature on the transforming character of Europe. In this literature, Europe is commonly perceived as a conceptual rather than geographical entity that has been both historically and philosophically a "moving target" and, thus, so "elusive that it is doubtful whether [it has] any reality at all outside the imagination", as Kockel, Nic Craith, and Frykman (2012, 1) note. Instead of a factual reality, scholars have perceived Europe rather as an idea or narrative (e.g. Delanty 1995; Lee and Bideleux 20o9; Stone 2014). In conceptual histories and conceptual research into its politics (e.g. Stråth 200oa; 200ob; Wiesner and Schmidt-Gleim 2014), Europe has been taken as a changing, contested, and contingent political construction that is produced in diverse political discourses and debates. Indeed, Europe has been 'imagined' in numerous ways in the course of history and continues to be constructed through imaginations in politics, media, history writing, museums, heritage sites, literature, art, and everyday practices of and interaction between people living in the continent. This is also our approach. For us, Europe is a fluid and constantly transforming idea that is constructed through and in relation to various discourses, meanings, and practices; it is intertwined with spatial and temporal scales.

In both public discourses and EU policy rhetoric, Europe is often represented as a singular and discernible unit, yet paradoxically left as an abstract and undefined entity. Yet, the continent has been, and still is, divided by various concrete physical boundaries, as well as symbolic and discursive divisions that influence people's notions of Europe, and of what and who belongs to it. 
These boundaries and divisions have contributed to creating diverse political, spatial, religious, cultural, and social internal 'others' in Europe's history, such as the Roma and Jews, whose 'otherness' depends on their various positions in European societies. Due to historical and recent internal boundaries, such as the division between the Eastern and Western blocs, the idea of Europe differs considerably between different geographical European locations (Malmborg and Stråth 2002; Straczuk 2012). The ideas also vary between people belonging to different social and educational strata (Lähdesmäki 2014c).

Internal divisions are not the only factor in differing conceptions of Europe. Various scholars have noted how the idea of Europe has been and continues to be constructed in relation to Europe's external 'others' (Stråth 200oa; Brague 2002; Pagden 2002; Wiesner and Schmidt 2014; Schmidt-Gleim 2014). Ambivalence towards these 'others' has been manifested in concrete relations with non-European peoples but also through creating images of the 'other' based not on observation or personal experience but on psychological drives, as Passerini (2002, 201-202) claims (on the Eurocentric view in past studies, see also Clifford and Marcus 1986). The indivisible nature of these concrete and imaginary relations is underlined by studies that emphasize how attempts to define the idea of Europe as a mentally and culturally unified continent have strengthened in periods when the continent has been perceived as being under threat. The idea of Europe and a European identity have been commonly formulated through diverse antitheses of Europe and perceived threats to it, such as the Turks, Russians, American or Asian economic powers, or Islam, just to mention a few (Mikkeli 1998). The attempts to define Europe through its 'other' have also culminated in the views of Europe as more progressive and civilized than other continents, thus furthering perceptions of racial superiority.

Similarly to Europe, the EU has been explored and explained in various studies through its relations to the 'other' (e.g. Shore 2006; Eder 2006; Wilken 2012). As Wilken $(2012,132)$ notes, "the EU itself may be defined as a union of Others", as its member states have been or still are the 'other' to some other member states. Since the 196os, policy discourses of the European Community, and later the EU, have defined a European identity in terms of common values, such as democracy, freedom, human rights, and the rule of law. In this discourse, 'Europe's other' is elicited from totalitarian and undemocratic regimes and their politics, thus as a negation of the aforementioned 'European' values (Wilken 2012).

The enlargement of the EU has transformed the concrete divisions in Europe but simultaneously created new ones between the Union and the non-EU states, and consequently fueled discussions about whether countries on the borders of the EU belong to Europe. EU enlargements have produced 'liminal positions', characterized by the ambiguity of "being Europe but not 
quite Europe" and by being half-insider-half-outsider, as Mälksoo (2009, 67) describes the condition of the Baltic countries after the EU's eastern enlargement in 2004.

The EU's 'others' have also been distinguished in time. In the EU's own history discourse, European integration has been justified by appealing to the need to prevent a return to Europe's warlike past, particularly the horrors of World War II and the political division of Europe during the Cold War (Lähdesmäki 2017a). In this discourse, past wars, struggles, and conflicts, such as the closed borders between the Eastern and Western blocs after World War II, are compared to the imagined presence of the EU represented by its positive virtues and values in EU policy discourse, such as peace, tolerance, solidarity, and free movement. As EU history discourse commonly narrates the difficult pasts of Europe as located in the history of nation states, this leads to the discourse positioning a 'Europe of the nation states' as the EU's 'other' (Wilken 2012, 133; see also Hellström 2006, 94; Lähdesmäki 2017a).

The terms Europe and the EU are often intertwined in the EU policy rhetoric. This intertwinement is particularly created through EU initiatives in which the idea of Europe is emphasized, constructed, and promoted - but also conditioned - by the EU. We use the term EUrope to refer to this kind of discursive intertwinement in which Europe as a geographical continent and the EU as an institutional entity are closely linked without making any clear distinction between them (Lähdesmäki et al. 2020; Turunen 2020). The discourse of EUrope is also commonly used in media discussions and everyday talk - and thus occurs in our data from the participants in EU initiatives. This is not surprising, as EUrope is a construction and an ideal that the EU cultural initiatives seek to advance.

Due to the fluidity of the notion of Europe and its nature as an imagination, idea, and narrative, it is difficult to distinguish Europe as a noun from the 'European' as an adjective. It is even more difficult to distinguish the concept of 'Europeanness' as a quality or characteristic of being European. All these different aspects of what Europe is, who belongs to it, and what is common or typical to 'Europeans', intertwine in political, cultural, and everyday discussions. This is why we do not seek to distinguish clearly between them in our book but rather perceive them are inseparable components of the same idea or imagination.

To scrutinize our fluid, transforming, and 'moving target', Europe, and how it is understood and given meanings from below in the context of EU cultural 
initiatives, our research methods need to allow different 'voices' to be heard and show the sensitivity to understand them. Ethnography enables us to approach the processes of constructing Europe and the 'European' among diverse people. Due to our thematic focus, we describe our methodology as 'ethnography of Europeanization' in which the emphasis is not (only) on participation in EU cultural initiatives but on Europe itself as an idea and an ongoing process constructed and governed by various actors at different levels. Previous ethnographic studies of EU cultural initiatives have mainly focused on actors, policy makers, and 'EU elites' operating from 'above' (e.g. Shore 2000; Sassatelli 2009), while ethnographic studies with an interest in cultural notions of Europe at the micro level do not usually deal with the EU's cultural initiatives or policies (e.g. Macdonald 2013). In our ethnography, we investigate how the participants in our three cases discursively and performatively give meanings to and construct Europe and the 'European' from below within the framework of the EU's politics of belonging. These meaning-making processes are based on finding connections and similarities between people and cultural features in Europe, but also on making distinctions between 'us' and 'them', as our analysis shows.

Our book is structured in eight chapters. Following this first introductory chapter, we discuss five core concepts of this book, culture, identity, belonging, participation, and citizenship, and their intertwined nature in Chapter 2. Our concepts and diverse meanings related to them stem from the policy discourses related to our case studies and the EU initiatives, as well as the ethnographic data created and gathered among their participants and visitors. We claim that these concepts form the core of the EU's politics of belonging. This is where we lay the theoretical and methodological foundations of our book: politics of belonging and ethnography of Europeanization.

Chapter 3 provides an overview of the development of the EU cultural policy and initiatives. Here, we introduce in more detail the EU's central programmes regarding culture (e.g. Culture 200o, Culture, and Creative Europe) that form the common policy framework for all the three cases in the book. In this chapter, we discuss the role of EU cultural policy in the Union's politics of belonging by distinguishing two entwined modes, or clusters, of creating belonging: an identity-building agenda and a participatory agenda.

The case studies follow in Chapters 4, 5, and 6, focusing on meso- and, particularly, micro-level data. Each of these chapters start by exploring the construction of Europe and the 'European' in the meso-level material, highlighting the 'voice' of local managers of these EU initiatives. This material includes ECOC bid books and promotional and information material of the ECC project and EHL sites. After this, the analysis moves to the micro level, investigating our field research data and discussing how participants in these initiatives give meanings to Europe and the 'European' in a variety of ways. The case 
studies share a common theoretical framework - politics of belonging - and a common methodological approach - ethnography of Europeanization - but in each case, we deal with the data and perceive themes from it in different ways. These differences stem from the contexts of the case initiatives and their implementation, as well as the type of data created and gathered during the fieldwork.

Chapter 7 compares the findings from the case studies and traces similarities and differences in participants' notions of Europe and the 'European'. These similarities and differences are interpreted in the context of the case initiatives and transforming reality in Europe in the 2010s. In this chapter, we focus on the interrelation between the social locations and views of our participants. We discuss how various background factors - such as gender, age, nationality, education, and activeness in cultural participation - affect their notions of Europe and the 'European'.

To conclude, in Chapter 8 we summarize how the notions of 'Europe' and the 'European' are constructed in EU cultural initiatives from below by perceiving Europe as characterized by diversity, mobility, nationalities, languages, politics, culture, and temporal, spatial, and social relations. Based on these results, we then formulate two dominant strands of European narratives. While the first of these emphasizes Europe in terms of cultural differences and distinct nation states, the second underlines a personal approach to belonging to Europe and is associated with affective experiences that are used to construct a notion of a transnational 'shared space' in Europe. In the conclusion, we explore the intertwined cultural and social dimensions of Europe and discuss the politics of belonging on a more abstract level. We stress the contradictory notions of belonging and non-belonging to Europe and how ideas of Europe are constructed in relation to 'others' inside and outside Europe. Our data reveals various inclusive and solidarity-based notions of 'Europe' that emphasize diversity in Europe. However, it also reveals explicitly and implicitly exclusive notions in which 'Europe' and the 'European' are based on bordering and making distinctions between 'us' and 'them'.

In this book, we examine how Europe and the 'European' are constructed from below. As this examination is grounded in research about EU-level policy discourses on Europe, we are able to explore differences and similarities between the notions of Europe from below and from above - between participants in EU cultural initiatives and EU policy discourse. Our exploration of the dynamics between EU cultural policy and the experiences of people participating in its initiatives reveals several gaps in the aims and effects of EU policies. As a core result of this exploration, we propose that 'Europe' and the 'European' are constructed in EU cultural initiatives not top-down or bottom-up but as an 
interrelated two-way process comprised of personal everyday experiences and interaction between Europeans and 'banal', well-known, and often-repeated representations and narratives of the continent and its inhabitants.

\section{References}

Aiello, G., and C. Thurlow. 2006. "Symbolic Capitals: Visual Discourse and Intercultural Exchange in the European Capitals of Culture Scheme." Language and Intercultural Communication 6 (2): 148-162.

Antonsich, M. 2008. "The Narration of Europe in 'National' and 'Post-national' Terms: Gauging the Gap between Normative Discourses and People's Views." European Journal of Social Theory 11 (4): 505-522.

Bache, I., and M. Flinders. 2004. "Themes and Issues in Multi-level Governance". In Multi-level Governance, edited by I. Bache and M. Flinders, 1-14. Oxford: Oxford University Press.

Beck, U., and E. Grande. 2007. Cosmopolitan Europe. Cambridge: Polity Press.

Berg, C., and H. Rommetvedt. 20og. Stavanger-regionen som europeisk kulturhovedstad slik innbyggerne ser det. Rapport 203. Stavanger: International Research Institute of Stavanger.

Bergsgard, N. A., and A. Vassenden. 2011. "The Legacy of Stavanger as Capital of Culture in Europe 2008: Watershed or Puff of Wind?" International Journal of Cultural Policy $17(3): 301-320$.

Brague, R. 2002. Eccentric Culture: A Theory of Western Civilization. South Bend, Ind.: St. Augustine's Press.

Bruter, M. 2003. "Winning Hearts and Minds for Europe. The Impact of News and Symbols on Civic and Cultural European Identity." Comparative Political Studies 36 (10): 1148-1179.

Bruter, M. 2004. "Civic and Cultural Components of a European Identity: A Pilot Model of Measurement of Citizens' Levels." In Transnational Identities. Becoming European in the $E U$, edited by R. K. Herrmann, T. Risse, and M. B. Brewer, 186-213. Oxford: Rowman \& Battlefield.

Bruter, M. 2005. Citizens of Europe? The Emergence of a Mass European Identity. New York: Palgrave Macmillan.

Calligaro, O. 2010. "EU Action in the Field of Heritage: A Contribution to the Discussion on the Role of Culture in the European Integration Process." In Cultures nationales et identité communautaire: Un défi pour l'Europe?, edited by M. Beers and J. Raflik, 87-98. Berlin: Peter Lang.

Calligaro, O. 2013. Negotiating Europe: EU Promotion of Europeanness Since the 1950 . New York: Palgrave Macmillan. 
Campbell, P. 2011. "Creative Industries in a European Capital of Culture." International Journal of Cultural Policy 17 (5): 510-522.

Čeginskas, V. L. A., and S. Kaasik-Krogerus. 2020. "Politics of Solidarity in the Context of European Heritage. The Cases of the European Solidarity Centre and Hambach Castle." International Journal of Heritage Studies 26 (10): 998-1012. doi: 10.1080/13527258.2019.1663235.

Checkel, J. T., and P. J. Katzenstein, eds. 2009. European Identity. Cambridge: Cambridge University Press.

Clifford, J., and G. E. Marcus, eds. 1986. Writing Culture. The Poetics and Politics of Ethnography. Berkeley and Los Angeles: University of California Press.

Delanty, G. 1995. Inventing Europe: Idea, Identity, Reality. Basingstoke: MacMillan Press.

Eder, K. 2006. "Europe's Borders: The Narrative Construction of the Boundaries of Europe." European Journal of Social Theory 9 (2): 255-271.

EP\&C (European Parliament and the Council). 2006. "Decision NO 1855/2006/EC of the European Parliament and of the Council of 12 December 2006 Establishing the Culture Programme (2007 to 2013)." Official Journal of the European Union L 372: $1-11$.

EP\&C (European Parliament and the Council). 2013. "Regulation (EU) NO 1295/2013 of the European Parliament and of the Council of 11 December 2013 Establishing the Creative Europe Programme (2014 to 2020) and repealing Decisions No 1718/2006/ EC, No 1855/2006/EC and No 1041/2009/EC." Official Journal of the European Union L 347: 221-237.

EP\&C (European Parliament and the Council). 2011. "Decision No. 1194/2011/EU of the European Parliament and of the Council of 16 November 2011: Establishing a European Union Action for the European Heritage Label." Official Journal of the European Union L 303: 1-9.

Falk, M., and E. Hagsten. 2017. "Measuring the Impact of the European Capital of Culture Programme on Overnight Stays: Evidence for the Last Two Decades." European Planning Studies 25 (12): 2175-2191.

García, B. 2004a. "Cultural Policy in European Cities: Lessons from Experience, Prospects for the Future." Local Economy 19 (4): 312-326.

García, B. 2004b. "Urban Regeneration, Arts Programming and Major Events: Glasgow 1990, Sydney 2000 and Barcelona 2004." International Journal for Cultural Policy 10 (1): 103-118.

García, B. 2005. "Deconstructing the City of Culture: The Long-Term Cultural Legacies of Glasgow 199o." Urban Studies 42 (5): 841-868.

García, B. 2010. Media Impact Assessment (part II): Evolving Press and Broadcast Narratives on Liverpool from 1996 to 2009. Liverpool: University of Liverpool.

Hansen, K. 2002. "Festivals, Spatiality and the New Europe." Ethnologia Europaea 32 (2): $19-36$. 
Heikkinen, T. 2000. "In from the Margins: The City of Culture 2000 and the Image Transformation of Helsinki." International Journal of Cultural Policy 6 (2): 201-218.

Hellström, A. 2006. Bringing Europe down to Earth. Lund: Lund University Press.

Herrero, L. C., J. Á. Sanz, M. Devesa, A. Bedate, and M. J. del Barrio. 20o6. "The Economic Impact of Cultural Events: A Case-Study of Salamanca 2002, European Capital of Culture." European Urban and Regional Studies 13 (1): 41-57.

Herrmann, R. K., and M. B. Brewer. 2004. "Identities and Institutions: Becoming European in the EU." In Transnational Identities. Becoming European in the EU, edited by R. K. Herrmann, T. Risse, and M. B. Brewer, 1-22. Oxford: Rowman \& Battlefield.

Hooghe, L., and G. Marks. 20o1. Multi-level Governance and European Integration. Lanham: Rowman and Littlefield.

Hudec, O., and P. Džupka. 2016. "Culture-led Regeneration through the Young Generation: Košice as the European Capital of Culture." European Urban and Regional Studies 23 (3): 531-538.

Jakubowski, A., K. Hausler, and F. Fiorentini, eds. 2019. Cultural Heritage in the European Union. Leiden: Brill.

Jenkins, R. 2008. “The Ambiguity of Europe." European Societies 10 (2):153-176.

Kaasik-Krogerus, S. 2019. "Politics of Mobility and Stability in Authorizing European Heritage: Estonia's Great Guild Hall.” In Dissonant Heritages and Memories in Contemporary Europe, edited by T. Lähdesmäki, L. Passerini, S. Kaasik-Krogerus, and I.van Huis, 157-181. New York: Palgrave Macmillan.

Kaina, V., I. P. Karolewski, and S. Kuhn, eds. 2015. European Identity Revisited: New Approaches and Recent Empirical Evidence. London: Routledge.

Kaiser, S. 2014. The European Heritage Label: A Critical Review of a New EU Policy. Unpublished MA Thesis, University of Illinois, UsA.

Kandyla, A. 2015. "The Creative Europe Programme: Policy-Making Dynamics and Outcomes." In Cultural Governance and the European Union: Protecting and Promoting Cultural Diversity in Europe, edited by E. Psychogiopoulou, 49-6o. New York: Palgrave Macmillan.

Karlsson, K.-G. 2010. "The Uses of History and the Third Wave of Europeanisation." In A European Memory? Contested Histories and Politics of Remembrance, edited by M. Pakier and B. Stråth, 38-55. New York: Berghahn Books.

Kockel, U., M. Nic Craith, and J. Frykman. 2012. "Introduction: The Frontiers of Europe and European Ethnology." In A Companion to the Anthropology of Europe, edited by U. Kockel, M. Nic Craith, and J. Frykman, 1-10. Oxford: Blackwell Publishing.

Lähdesmäki, T. 2014a. "The EU's Explicit and Implicit Heritage Politics." European Societies 16 (3): 401-421.

Lähdesmäki, T. 2014b. "Transnational Heritage in the Making. Strategies for Narrating Cultural Heritage as European in the Intergovernmental Initiative of the European Heritage Label." Ethnologica Europaea 44 (1): 75-93. 
Lähdesmäki, T. 2014c. "The Influence on Cultural Competence on the Interpretations of Territorial Identities in European Capitals of Culture." Baltic Journal of European Studies 4 (1): 69-96.

Lähdesmäki, T. 2014d. Identity Politics in the European Capital of Culture Initiative. Joensuu: University of Eastern Finland.

Lähdesmäki, T. 2014e. "Discourses of Europeanness in the Reception of the European Capital of Culture Events: The Case of Pécs 2010.” European Urban and Regional Studies 21 (2): 191-205.

Lähdesmäki, T. 2016. "Politics of Tangibility, Intangibility, and Place in the Making of European Cultural Heritage in EU Heritage Policy." International Journal of Heritage Studies 22 (10): 766-780.

Lähdesmäki, T. 2017a. "Narrativity and Intertextuality in the Making of a Shared European Memory." Journal of Contemporary European Studies 25 (1): 57-72.

Lähdesmäki, T. 2017b. "Politics of Affect in the EU Heritage Policy Discourse: An Analysis of Promotional Videos of Sites Awarded with the European Heritage Label." International Journal of Heritage Studies 23 (8): 709-722.

Lähdesmäki, T. 2020. "Politics of Belonging in Brussels' European Quarter." International Journal of Heritage Studies 26 (10): 979-997. doi: 10.1080/13527258.2019.1663237.

Lähdesmäki, T., V. L. A. Čeginskas, S. Kaasik-Krogerus, K. Mäkinen, and J. Turunen. 2020. Creating and Governing Cultural Heritage in the European Union: The European Heritage Label. London: Routledge.

Lähdesmäki, T., S. Kaasik-Krogerus, and K. Mäkinen. 2019. "Genealogy of the Concept of Heritage in the European Commission's Policy Discourse." Contributions to the History of Concepts 14 (1): 115-139.

Lähdesmäki, T., and K. Mäkinen. 2019. “The 'European Significance’ of Heritage: Politics of Scale in EU Heritage Policy Discourse." In Politics of Scale. New Directions in Critical Heritage Studies, edited by T. Lähdesmäki, S. Thomas, and Y. Zhu, 36-49. New York: Berghahn's Books.

Lassur, S., K. Tafel-Viia, K. Summatavet, and E. Terk. 2010. "Intertwining of Drivers in Formation of New Policy Focus: Case of Creative Industries in Tallinn." The Nordic Journal of Cultural Policy 13 (1): 59-85.

Lee, C., and R. Bideleux. 20o9. "Europe': What kind of idea?" The European Legacy 14 (2): $163-176$.

Liz, M. 2016. Euro-Visions: Europe in Contemporary Cinema. New York: Bloomsbury.

Macdonald, S., 2013. Memorylands. Heritage and Identity in Europe Today. London: Routledge.

Mäkinen, K. 2012. Ohjelmoidut eurooppalaiset. Kansalaisuusja kulttuuriEU-asiakirjoissa [Programmed Europeans. Citizenship and Culture in EU Documents]. Jyväskylä: University of Jyväskylä. 
Mäkinen, K. 2014. "Constructing Europe as an Area via EU Documents on Citizenship and Culture." In The Meanings of Europe: Changes and Exchanges of a Contested Concept edited by C. Wiesner and M. Schmidt-Gleim, 130-143. London: Routledge.

Mälksoo, M. 20o9. "Liminality and Contested Europeanness. Conflicting Memory Politics in the Baltic Space." In Identity and Foreign Policy. Baltic-Russian Relations and European Integration, edited by E. Berg and P. Ehin, 65-84. London: Routledge.

Malmborg, M. af, and B. Stråth, eds. 2002. The Meaning of Europe: Variety and Contention Within and Among Nations. Oxford: Berg.

Mayer, F. C., and J. Palmowski. 2004. "European Identities and the EU - The Ties That Bind the People of Europe." Journal of Common Market Studies 42 (3): 573-598.

Mikkeli, H. 1998. Europe as an Idea and an Identity. Basingstoke: Palgrave Macmillan.

Monnet, J. 1955. Les Etats-Unis d'Europe ont Commencé. Paris: Laffont.

Myerscough, J. 1994. European Cities of Culture and Cultural Months. Glasgow: The Network of Cultural Cities of Europe.

Näss, H. E. 2009. A New Agenda? The European Union and Cultural Policy. London: Alliance Publishing Trust.

Näss, H. E. 2010. "The Ambiguities of Intercultural Dialogue: Critical Perspectives on the European Union's New Agenda for Culture." Journal of Intercultural Communication 23. Accessed 23 March 2020. https://www.immi.se/intercultural/nr23/ nass.htm

Niklasson, E. 2017. "The Janus-Face of European Heritage: Revisiting the Rhetoric of Europe-Making in EU Cultural Politics." Journal of Social Archaeology 17 (2): 138-162.

Nousiainen, M., and K. Mäkinen. 2015. "Multilevel Governance and Participation: Interpreting Democracy in EU-programmes." European Politics and Society 16 (2): 208-223.

O'Callaghan, C. 2011. "Urban Anxieties and Creative Tensions in the European Capital of Culture 2005: 'It Couldn't Just Be about Cork, Like." International Journal of Cultural Policy 18 (2): 185-204.

Oerters, K., and J. Mittag. 2008. "European Capitals of Culture as Incentives for Local Transformation and Creative Economies: Tendencies - Examples - Assessments." In Whose Culture(s)? Proceedings of the Second Annual Conference of the University Network of European Capitals of Culture held in Liverpool 16-17 Oct 2008, edited by W. Coudenys, 70-97. Pécs: The University Network of European Capitals of Culture.

Pagden, A., ed., 2002. The Idea of Europe. From Antiquity to the European Union. Cambridge: Cambridge University Press.

Palmer, R. 2004a. European Cities and Capitals of Culture. Part I. Brussels: European Commission \& Palmer/Rae Associates.

Palmer, R. 2004b. European Cities and Capitals of Culture: City Reports. Part II. Brussels: European Commission \& Palmer/Rae Associates. 
Palmer, R., and G. Richards. 2007. European Cultural Capital Report. Arnhem: ATLAS.

Palmer, R., and G. Richards. 2009. European Cultural Capital Report 2. Arnhem: ATLAS.

Palmer, R., G. Richards, and D. Dodd. 2011. European Cultural Capital Report 3. Arnhem: ATLAS.

Palmer, R., G. Richards, and D. Dodd. 2012. European Cultural Capital Report 4. Arnhem: ATLAS.

Patel, K. K. 2013. "Introduction." In The Cultural Politics of Europe: European Capitals of Culture and European Union Since the 1980s, edited by K. K. Patel, 1-15. London: Routledge.

Passerini, L. 2002. "From the Ironies of Identity to the Identity of Irony." In The Idea of Europe. From Antiquity to the European Union, edited by A. Pagden, 191-208. Cambridge: Cambridge University Press.

Piattoni, S. 20o9. "Multi-level Governance: A Historical and Conceptual Analysis." European Integration 31 (2): 163-180.

Pichler, F. 2008. "European Identities from Below: Meanings of Identification with Europe." Perspectives on European Politics and Society 9 (4): 411-430.

Pichler, F. 20o9. "Cosmopolitan Europe. Views and Identity." European Societies 11 (1): $3^{-24}$.

Potschka, C., M. Fuchs, and A. Królikowski. 2013. "Review of European Expert Network on Culture's Audience Building and the Future Creative Europe Programme, 2012." Cultural Trends 22 (3/4): 265-269.

Prutsch, M. J. 2013. European Historical Memory: Policies, Challenges and Perspectives. Directorate-General for Internal Policies. Policy Department B: Structural and Cohesion Policies. Culture and Education. Brussels: European Parliament.

Psychogiopoulou, E. 2008. Integration of Cultural Considerations in European Union Law and Policies. Leiden: Martinus Nijhoff Publishers.

Reme, E. 2002. "Exhibition and Experience of Cultural Identity. The Case of BergerEuropean City of Culture." Ethnologia Europaea 32 (2): 37-46.

Richards, G. 200o. "The European Cultural Capital Event: Strategic Weapon in the Cultural Arms Race?" Cultural Policy 6 (2): 159-181.

Richards, G., and R. Palmer. 2010. Eventful Cities: Cultural Management and Urban Revitalisation. London: Routledge.

Richards, G., and I. Rotariu. 2011. Ten Years of Cultural Development in Sibiu: The European Cultural Capital and Beyond. Arnhem: ATLAs.

Richards, G., and J. Wilson. 2004. "The Impact of Cultural Events on City Image: Rotterdam, Cultural Capital of Europe 2001." Urban Studies 41 (10): 1931-1951.

Risse, T. 2003. "European Identity and the Heritage of National Culture." In Rethinking Heritage. Cultures and Politics in Europe, edited by R. S. Peckham, 74-89. London: I.B.Tauris. 
Risse, T. 2006. "Neofunctionalism, European Identity, and the Puzzles of European Integration." Journal of European Public Policy 12 (2): 291-309.

Rommetvedt, H. 2008. "Beliefs in Culture as an Instrument for Regional Development: The Case of Stavanger, European Capital of Culture 2008." In Regional and Urban Regeneration in European Peripheries: What Role for Culture?, edited by L. Malíková and M. Sirák, 59-63. Bratislava: Institute of Public Policy.

Rosamond, B. 200o. Theories of European Integration. Basingstoke: Palgrave.

Sassatelli, M. 2002. "Imagined Europe." European Journal of Social Theory 5 (4): 435-451.

Sassatelli, M. 2006. "The Logic of Europeanizing Cultural Policy." In Transcultural Europe. Cultural Policy in a Changing Europe, edited by U. H. Meinhof and A. Triandafyllidou, 24-42. Basingstoke: Palgrave Macmillan.

Sassatelli, M. 2009. Becoming Europeans. Cultural Identity and Cultural Policies. New York: Palgrave Macmillan.

Sassatelli, M. 2013. "Europe's Several Capitals of Culture: From Celebration to Regeneration, to Polycentric Capitalization." In The Cultural Politics of Europe. European Capitals of Culture and European Union Since the 1980s, edited by K. K. Patel, 55-71. London: Routledge.

Schuman, R. 1963. Pour l'Europe. Paris: Nagel.

Schmidt-Gleim, M. 2014. "Europe and the Spectre of the Barbarian." In The Meanings of Europe. Changes and Exchanges of a Contested Concept, edited by C. Wiesner, and M. Schmidt-Gleim, 33-46. London: Routledge.

Shore, C. 1993. "Inventing the 'People's Europe': Critical Approaches to European Community 'Cultural Policy.'” Man 28 (4): 779-80o.

Shore, C., 200o. Building Europe: The Cultural Politics of European Integration. London: Routledge.

Shore, C. 2006 "Government without Statehood? Anthropological Perspectives on Governance and Sovereignty in the European Union." European Law Journal 12 (6): 709-724.

Staiger, U. 2013. "The European Capitals of Culture in Context: Cultural Policy and the European Integration Process." In The Cultural Politics of Europe. European Capitals of Culture and European Union Since the 1980s, edited by K. K. Patel, 19-38. London: Routledge.

Straczuk, J. 2012. "Local Practices of European Identity on the New Eastern Borders of the EU." In A Companion to the Anthropology of Europe, edited by U. Kockel, M. Nic Craith, and J. Frykman, 199-211. Oxford: Blackwell Publishing.

Stone, D. 2014. Goodbye to All That? The Story of Europe since 1945. Oxford: Oxford University Press.

Stråth, B. ed. 200oa. Europe and the Other and Europe as the Other. Brussels: PIE-Peter Lang. 
Stråth, B. ed. 20oob. Myth and Memory on the Construction of Community. Historical Patterns in Europe and Beyond. Brussels: PIE-Peter Lang.

Suárez C., and M. Luz. 2018. "Bridging the Competing Views of European Cultural Integration: The Transformative View of Culture as a Means to Promote Growth, Employment and Social Cohesion." Romanian Review of Social Sciences 8 (14): 28-41.

Treaty of Paris 1951. Treaty Constituting the European Coal and Steel Community. Luxembourg: Publishing Services of the European Communities.

Triandafyllidou, A., and R. Gropas. 2015. What is Europe? New York: Palgrave.

Turunen, J. 202O. “Decolonising European Minds through Heritage." International Journal of Heritage Studies 26 (10): 1013-1028. doi:10.1080/13527258.2019.1678051.

Turunen. J., V. L. A Čeginskas, S. Kaasik-Krogerus, T. Lähdesmäki, and K. Mäkinen. forthcoming 2020. "Poly-Space: Creating New Concepts through Reflexive Team Ethnography." In Challenges and Solutions in Ethnographic Research: Ethnography with a Twist, edited by T. Lähdesmäki, E. Koskinen-Koivisto, V. L. A. Čeginskas, and A.-K. Koistinen, 3-20. London: Routledge.

Vos, C. 2017. "European Integration through 'Soft Conditionality'. The Contribution of Culture to EU Enlargement in Southeast Europe." International Journal of Cultural Policy 23 (6): 675-689.

Waechter, N. 2019. The Construction of European Identity among Ethnic Minorities: 'Euro-minorities' in Generational Perspective. London: Routledge.

Wiesner, C., and M. Schmidt-Gleim. 2014. "The Meanings of Europe: Introduction." In The Meanings of Europe. Changes and Exchanges of a Contested Concept, edited by C. Wiesner, and M. Schmidt-Gleim, 1-15. London: Routledge.

Wilken, L. 2012. "Anthropological Studies of European Identity Construction." In $A$ Companion to the Anthropology of Europe, edited by U. Kockel, M. Nic Craith, and J. Frykman, 125-144. Oxford: Blackwell Publishing.

Yuval-Davis, N. 2006. "Belonging and the Politics of Belonging." Patterns of Prejudice 40 (3): 197-214.

Yuval-Davis, N. 2011. The Politics of Belonging. Intersectional Contestations. London: Sage.

Žilič-Fišer, S., and K. Erjavec. 2017. "The Political Impact of the European Capital of Culture: 'Maribor 2012 Gave Us the Power to Change the Regime.' International Journal of Cultural Policy 23 (5): 581-596.

Zito, A., S. Eckersley, and S. Turner. 2019. "The instruments of European heritage." In Dimensions of Heritage and Memory. Multiple Europes and the Politics of Crisis, edited by C. Whitehead, S. Eckersley, M. Daugbjerg, and G. Bozoğlu, 50-71. London: Routledge. 